\title{
Climatogenic north-south asymmetry of local glaciers in Spitsbergen and other parts of the Arctic
}

\author{
Ian S. EVANS, Nicholas J. COX \\ Department of Geography, Durham University, Durham DH1 3LE, UK \\ E-mail: i.s.evans@durham.ac.uk
}

\begin{abstract}
Although World Glacier Inventory (WGI) data for 241 local glaciers ( $>1 \mathrm{~km}^{2}$ in area) in Svalbard show a mean aspect of $014^{\circ} \pm 24^{\circ}$, their mid-altitudes are lowest for an aspect of $109^{\circ} \pm 46^{\circ}$, which is inconsistent. Further data are generated here for the altitude, length and source aspect of 205 local glaciers (0.3-6.0 km long) in the main area of local glaciation in Svalbard, Nordenskiöld Land. All four mountain blocks have mean glacier source aspects of $356^{\circ}$ to $018^{\circ}$; the overall mean is $011^{\circ} \pm 8^{\circ}$. Mid-altitudes are lowest at $042^{\circ} \pm 21^{\circ}$, predicted to be $53 \mathrm{~m}$ lower than on opposite aspects. Lowest altitudes are predicted at $009^{\circ}$ to $030^{\circ}$, averaging $157 \mathrm{~m}$ lower than on opposite aspects. These results show that local, land-terminating glaciers around $78^{\circ} \mathrm{N}$ are affected more by north-south radiation receipt contrasts than by wind effects, consistent with the trend found across most other Arctic regions. It is concluded that, although weaker than in mid-latitudes, contrasts due to slope climates are substantial even in Arctic glaciers. This is apparent only when small, steep glaciers are inventoried: WGI data are incomplete and users need to check the thresholds of coverage.
\end{abstract}

\section{INTRODUCTION}

The distribution of glaciers, both locally and regionally, provides valuable information on climate in mountain regions. Indeed, the paucity of climatic observations at altitude means that glaciers often constitute the most important sources of evidence for spatial variations in climate in mountain regions with numerous glaciers (Humlum, 2002). An economical method for investigating regional variations in climate, supplementing more resource-intensive studies of localized mass balance, lies in the interrogation of glacier inventory data, such as those contained in the World Glacier Inventory (WGI).

While most studies emphasize glacier altitudes, especially equilibrium-line altitudes (ELAs), as climate indicators, variations with aspect provide useful further evidence of cloudiness and wind regimes (Evans, 1977). Aspect tendencies, more specifically local asymmetry in mountain glaciation, relate essentially to glacier energy and mass balance on different slopes, modulated by topographic lineation. North-south contrasts in glacier balance and thus glacier distribution due to solar radiation incidence effects exist worldwide, but diminish toward the Poles and Equator (Evans and Cox, 2005). Topography permitting, it is expected that slope aspects with the most positive mass balance will generate more glaciers, and that these glaciers will have lower ELAs and mid-altitudes.

However, based on the WGI, a global survey by Evans and Cox (2005; Evans, 2006) identified anomalies in a number of Arctic datasets, where the favoured aspect (direction, azimuth) in terms of numbers of glaciers differed from that with the lowest glaciers. These anomalies are investigated here, with special reference to the glaciers of Spitsbergen, Svalbard.

Consistency between the favoured aspect for numbers and that for altitudes is expected if local asymmetry is related to glacier balance. Such consistency was found by Evans (2006) for non-Arctic regions. Recently Schiefer and others (2008, table 4) found consistency in eight out of ten regions in British Columbia (B.C.), Canada, with more glaciers facing between north and northeast; these glaciers reached lower altitudes and had lower mid-altitudes. The exceptions were the St Elias Range, where only one side is in B.C., and Vancouver Island, where there are too few southfacing glaciers to give a statistically significant altitude relation. Arctic anomalies therefore raise several questions:

1. Is the observed asymmetry of non-climatic origin, for example, because of topographic lineation?

2. In Svalbard, does the importance of tidewater glaciers bias the results?

3. Is there some problem with the data? Or

4. Is there some problem with the assumptions of the methodology?

In this paper, we investigate the possible causes of the previously reported anomalies in glacier aspect, length and gradient data for Svalbard using new inventory data, and compare our findings with results from other Arctic regions.

\section{METHODS}

Following on from recent work (e.g. Evans and Cox, 2005; Evans 2006), this paper deals with the variation of glacier numbers and glacier altitudes with accumulation-area aspect (direction, azimuth). As conventional linear statistics are inappropriate for circular data such as aspect, where $0^{\circ} \equiv 360^{\circ}$, the techniques used are vector analysis (for glacier numbers) and Fourier (circular, periodic, trigonometric) regression for altitudes. The vector mean is the net tendency, given by the aspect of the resultant vector: this can be derived graphically from a cumulative vector plot, or computationally via separate summation of sine and cosine components of aspect. 95\% confidence limits on mean direction are indicated by \pm throughout, using a nonparametric procedure from Fisher (1993).

The strength of any tendency to a single favoured aspect is given by the vector strength, the ratio of the length of the 
resultant to the total length of segments plotted. Both segments and resultants are measured in number of glaciers (or glacier sources). Vector strength measures unimodal deviation from a uniform distribution on the circle: it varies from 0 (uniform) to $100 \%$ (constant aspect).

The Fourier regression technique, detailed in Evans and Cox (2005) and Cox (2006), simply ensures that the same fitted value is given for $0^{\circ}$ as for $360^{\circ}$. This is achieved by multiple regression, on the cosine and sine components of aspect, rather than on aspect in degrees. The cosine coefficient expresses the north-south differences; the sine, the east-west differences.

\section{LOCAL ASYMMETRY IN SVALBARD: WGI DATA}

Evans and Cox (2005) showed that north-south (shade-sun) asymmetry is greatest in mid-latitudes, and declines to zero at the Equator and the Poles. There is, however, some scatter in the results for the Arctic. For example, local glaciers in Svalbard $\left(76-81^{\circ} \mathrm{N}\right)$ and Novaya Zemlya $\left(73-77^{\circ} \mathrm{N}\right)$ were a little lower on south-facing slopes, but this difference was insignificant (at $p=0.05$ ). For Svalbard (allowing for a quadratic spatial trend), the minimum altitude predicted for the 241 local glaciers in the WGI was for an aspect of $109 \pm 46^{\circ}$; this is inconsistent with the vector mean direction (of glacier numbers), which was $014^{\circ} \pm 24^{\circ}$. Also, the northward tendency for local glacier numbers contrasts with an eastward net tendency for tidewater glacier numbers: this may arise from the larger numbers reaching the east coasts of Svalbard. (Note that 73 of the local glaciers are tidewater glaciers (lowest altitude $=0$ or $1 \mathrm{~m}$ ), and roughly half the tidewater glaciers are local glaciers.) A dataset from H. Jiskoot (personal communication, 2007: cf. Jiskoot and others, 2000), revised from the WGI, gives similar results for aspect analyses.

Considering more closely the derivation of the WGI data for Svalbard provides some clues as to the causes of the results reported above. First, local glaciers are defined from WGI 'Primary classification' as classes 5 (valley glacier), 6 (mountain glacier) and 7 (glacieret and snowfield): other classes (ice sheet, ice field, ice cap, ice shelf, outlet glacier, rock glacier and 'uncertain or miscellaneous') are excluded. Of the 894 Svalbard glaciers in the WGI, only 406 were classified. Of these, 237 were valley glaciers, none were 'mountain glaciers' and four were 'glacierets' (supposedly very small glaciers, but these four range from 6.3 to $8 \mathrm{~km}^{2}$ ). Hence, this figure of 241 glaciers greatly underestimates the true number of local glaciers in Svalbard.

Second, Evans (2006, table 2) noted that the average length $(8861 \mathrm{~m})$ of Svalbard local glaciers from the WGI was more than twice that in any of the other 51 regions analysed, and the average gradient $\left(5.8^{\circ}\right)$ was less than half. It seems reasonable that gradients of Svalbard glaciers are lower than those of high mountain areas such as the Alps or central Asia. However, these WGI-based results are misleading. The WGI data are based on the Svalbard inventory of Hagen and others (1993), which gives fuller information. They state that only glaciers exceeding $1 \mathrm{~km}^{2}$ in area are listed separately; total areas of smaller glaciers are given for each region. For most glaciers with areas less than $5 \mathrm{~km}^{2}$, only latitude, longitude and area are given. Also, data for glaciers shorter than $5 \mathrm{~km}$ are often incomplete, and none are available for glaciers less than $1.5 \mathrm{~km}$ long and $1 \mathrm{~km}^{2}$ in area. Many glaciers are 'unclassified'. By contrast, in most regions, glaciers down to $0.01 \mathrm{~km}^{2}$ were inventoried in the WGI. As the missing glaciers in Svalbard are smaller and steeper, they are more influenced by slope mesoclimates, which are less variable on gently sloping large glaciers. Thus it is not surprising that asymmetry of local glaciers is imperfectly portrayed in the WGI data. Raper and Braithwaite (2009, fig. 4) also demonstrate the incomplete nature of the Svalbard data, compared with six other WGI regions.

Hence, limitations of WGI data for Svalbard mean that analyses of aspect and altitude are based on only 406 glaciers in total, 241 of which are local. Thus for the mountain block south of Longyearbyen for which 40 glacier sources are discussed below, only the largest four glaciers have altitude and aspect data in Hagen and others (1993) and in the WGI. Clearly these omissions make it difficult to represent the asymmetry of local glaciers, which is strongest for the smallest and steepest glaciers. Glaciers over $5 \mathrm{~km}^{2}$ in area are more likely to have multiple sources with various aspects, and information relevant to slope mesoclimates is blurred when (in the WGI) these are pooled to give a single accumulation-area aspect.

\section{CENTRAL SPITSBERGEN}

\section{Study area}

To address the issue discussed above, we have generated new glacier inventory data incorporating smaller glaciers, in the hope of achieving greater consistency with WGI data for other Arctic regions. For this exercise, only parts of Svalbard are relevant: the pattern of glaciation is of ice caps in the eastern islands (Nordauslandet, Edgeøya and Barentsøya) and of mountain ice fields with many glaciers descending to tidewater in northwest, northeast and southernmost Spitsbergen (Hagen and others, 2003; Dowdeswell and Hagen, 2004). ELA rises away from each coast, varying from $<200 \mathrm{~m}$ in parts of the west coast to $>800 \mathrm{~m}$ in the interior of northeast Spitsbergen, around middle Wijdefjorden (Liestøl, 1993), or from 300 to $700 \mathrm{~m}$ according to Hagen and others (2003). Local glaciation is thus confined mainly to central Spitsbergen, to the north-central peninsula (Andrée Land) between Woodfjorden and Wijdefjorden, and small areas on some west coast peninsulas: immediately south of Bellsund; west of Barentsburg; on the Brøggerhalvøya; and over the island Prins Karls Forland.

In central Spitsbergen, the relatively dry interior mountains around inner Isfjorden have a high ELA, with local glaciation throughout Dickson Land, Bünsow Land and most of Nordenskiöld Land. The latter is the largest contiguous area of local glaciation, has homogeneous structure (nearhorizontal, mainly Palaeogene rocks) and was selected as the study area (Fig. 1). It is limited to the west by the large ice mass of Grønfjordbre-Fridtjovbreen, and to the east by the area of large glaciers (some $>30 \mathrm{~km}^{2}$ ) around upper Reindalen. Other areas of local glaciation are difficult to separate from adjacent areas of ice fields, or provide too few glaciers for statistical analysis.

The study area is $75 \mathrm{~km} \times 35 \mathrm{~km}$, with glaciers between $14.3^{\circ}$ and $16.8^{\circ} \mathrm{E}$, and from $77.8^{\circ}$ to $78.3^{\circ} \mathrm{N}$. It is within the area studied by Humlum (2002), who discussed the climate and estimated that ELA varied between $300 \mathrm{~m}$ in the west and $900 \mathrm{~m}$ in the east of this study area, but mainly between 500 and $800 \mathrm{~m}$, with considerable local variations in relation to precipitation variations between 1300 and 


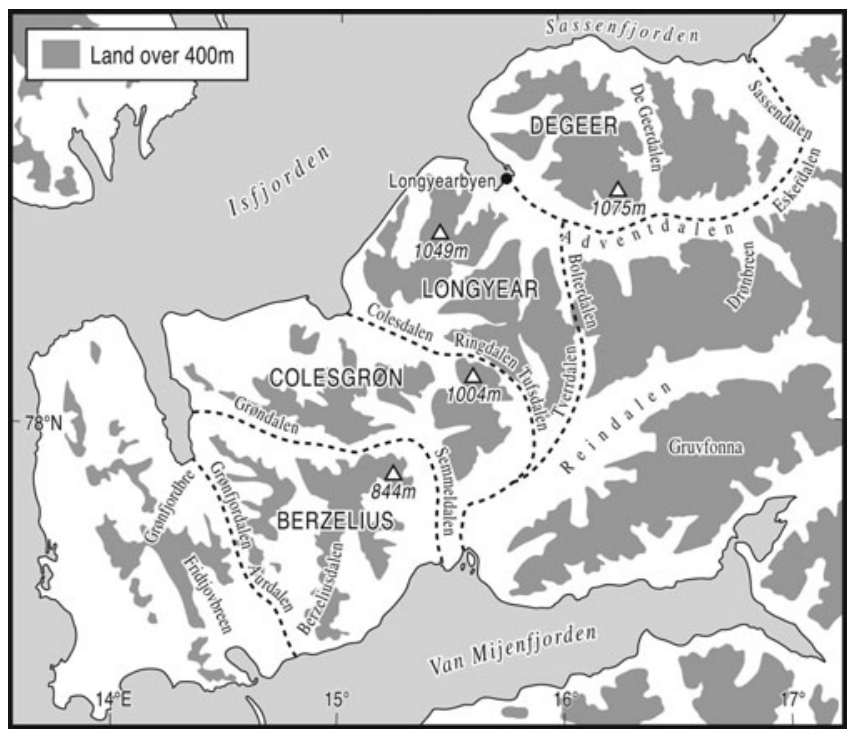

Fig. 1. Nordenskiöld Land, central Spitsbergen, showing definitions of the four mountain blocks analysed. Bounding valleys are named and the highest point in each block is indicated.

$400 \mathrm{~mm}$. Some of the glaciers are illustrated in Ziaja (2005) and in Ziaja and Pipała (2007), who emphasize the considerable recession since 1936. Nuth and others (2007) suggest that by $200720 \%$ of the 1936 glacier area in central Nordenskiöld Land had been lost. Humlum and Ziaja (2002) debate the difficulties of determining the limits of debriscovered ice in this permafrost region.

Analysis of glacier aspect statistics in relation to climate is best performed for mountain blocks bounded by valleys and low passes, so that slopes of all aspects can be included. Four such distinct blocks, each with a reasonable number of small glaciers but no large glaciers, were identified in northern and central Nordenskiöld Land between Grønfjorden and Sassenfjorden. From northeast (interior) to southwest, the mountain blocks (Fig. 1) are:

1. DeGeer, either side of De Geerdalen, between Eskerdalen, Adventdalen and Sassenfjorden. The only plateau glacier (Bassen, on Operafjellet) was excluded.

2. Longyear, south of Longyearbyen and Adventdalen, west of Bolterdalen-Tverrdalen and north of ColesdalenRingdalen-Tufsdalen.

3. ColesGrøn, between Colesdalen and Grøndalen, between Isfjorden and Reindalen and west of Tufsdalen.

4. Berzelius, between Grøndalen and Van Mijenfjorden, west of Semmeldalen and east of GrønfjorddalenAurdalen.

All four blocks have unlineated topography with ridges in various directions, producing no bias in valley-head or glacier direction. The glaciers lie mainly on well-bedded Palaeogene sedimentary rocks with gentle dips; there are some Cretaceous rocks in the DeGeer block.

\section{Data}

New glacier inventories were created for the four mountain blocks in Nordenskiöld Land, using the best available maps (Norsk Polarinstitutt, 2005). Although these are at the small scale of $1: 100000$, they have contours every $50 \mathrm{~m}$, are based on 1990-95 air photographs and portray glaciers with sufficient accuracy for present purposes. Better datasets were not available: DEMs and lidar cover only limited areas, usually single glaciers, and Google Earth coverage is very poor. We do not offer a completion of the Svalbard inventory, but we generate data sufficient to test the anomalies noted above. All the glaciers are land-terminating and, except for a few small slope glaciers, they are either cirque glaciers or valley glaciers. Glaciers down to $300 \mathrm{~m}$ long (e.g. triangular niche glaciers) were included, but the smallest mapped ice patches, in narrow gullies, were excluded. The largest glacier, Tavlebreen, is $6 \mathrm{~km}$ long and $11 \mathrm{~km}^{2}$ in area.

Accumulation (and ablation)-area aspects were estimated to 16 compass points (interval $22.5^{\circ}$ ) for each glacier source. This greater resolution is easily achieved and is clearly more appropriate to studies of aspect than the $45^{\circ}$ classes of the WGI. Each glacier source (usually a cirque) and its tongue was treated as a distinct unit. This gives appropriate weighting for aspect studies, while, in contrast, weighting single aspects by glacier area would produce distortions because of the averaging for large glaciers. Highest and lowest altitudes of the glacier were recorded, including debris-covered ice but excluding ice-cored moraine. These were averaged to give mid-range altitude (mid-altitude), which is closely related to ELA (Evans and Cox, 2005).

Including each source cirque as a separate entry permitted more precise specification of aspects and made inclusion of multiple-basin medium-sized glaciers more meaningful. It does, however, produce a potential problem in determining lowest altitudes for such glaciers. Where ice from different sources coalesced, it was divided along flowlines, splitting glacier tongues along medial moraines. The glacier unit from each source cirque could thus be given a different 'lowest altitude', with tributaries ending higher than the trunk flow. Coalescence over a long distance would modify lowest altitude by affecting glacier tongue thickness and surface area (compared with isolated glaciers), but no glaciers in the study area are over $6 \mathrm{~km}$ long: coalescence occurs over a maximum of $3 \mathrm{~km}$, so its effect on lowest altitudes is very limited.

\section{Central Spitsbergen results}

Vector analysis (Table 1) shows strong or marked asymmetry, with very high vector strengths of $50-75 \%$ (significant at $p=0.0001$ by Rayleigh's test) for each block. Mean accumulation-area aspects are consistently between north and north-northeast $\left(356^{\circ}\right.$ to $018^{\circ}$ ) (Figs 2 and 3 ). This is consistent with solar radiation having the greatest influence on the azimuthal variation of mass balance, as in many midlatitude mountains (Evans, 1977; Evans and Cox, 2005). The 95\% confidence limits for the four blocks overlap.

Regression of mid-altitude on the cosine and sine of azimuth fits a simple model with one maximum and one minimum, revealing the aspect with lowest mid-altitude. A 95\% confidence interval on this aspect can be calculated. This is likely to be the aspect with the most favourable glacier mass balance. The individual blocks have rather few glaciers for such analysis (especially, few south-facing sources): two give significant regressions and two are insignificant at $p=0.05$. Therefore it is best to combine the four blocks, totalling 205 glacier sources, but making allowance for the differences in mean glacier altitude between blocks by subtracting this from each altitude. Mean values of glacier 
Table 1. Results for glacier sources in four mountain blocks in Nordenskiöld Land, central Spitsbergen. Column headings: Number is of glaciers; Mean and Strength refer to the resultant vector; Mid is mid-range altitude, halfway between highest and lowest on a glacier; Low is terminal altitude; Cosine coefficients $(\mathrm{m})$ are for the north vs south term in a Fourier regression (see Methods section)

\begin{tabular}{|c|c|c|c|c|c|c|c|c|}
\hline \multirow[b]{2}{*}{ Block } & \multirow[b]{2}{*}{ Number } & \multicolumn{2}{|c|}{ Accumulation aspect } & \multicolumn{2}{|c|}{ Lowest aspect for: } & \multicolumn{2}{|c|}{ Cosine coeff. } & \multirow{2}{*}{$\begin{array}{l}\text { Mean } \\
\text { Mid }\end{array}$} \\
\hline & & Mean & Strength & Mid & Low & Mid & Low & \\
\hline DeGeer & 42 & $358^{\circ} \pm 25^{\circ}$ & $50 \%$ & $(p=0.42)$ & $26^{\circ} \pm 26^{\circ}$ & -22 & -73 & 602 \\
\hline Longyear & 40 & $13^{\circ} \pm 16^{\circ}$ & $72 \%$ & $12^{\circ} \pm 21^{\circ}$ & $19^{\circ} \pm 16^{\circ}$ & -104 & -199 & 645 \\
\hline ColesGrøn & 46 & $9^{\circ} \pm 13^{\circ}$ & $75 \%$ & $42^{\circ}(p=0.09)$ & $9^{\circ} \pm 17^{\circ}$ & -50 & -166 & 563 \\
\hline Berzelius & 77 & $18^{\circ} \pm 16^{\circ}$ & $53 \%$ & $(p=0.40)$ & $30^{\circ} \pm 35^{\circ}$ & -1 & -46 & 444 \\
\hline Total & 205 & $11^{\circ} \pm 8^{\circ}$ & $61 \%$ & $42^{\circ} \pm 41^{\circ}$ & $26^{\circ} \pm 15^{\circ}$ & -20 & -73 & 542 \\
\hline
\end{tabular}

mid-altitude for each block, from northeast (interior, DeGeer) to southwest (Berzelius), are 602, 645, 563 and $444 \mathrm{~m}$. Figure 4 a shows a weak but significant result $(p=0.027)$ for 'relative mid-altitude', with $R^{2}=0.03$, rmse $76.3 \mathrm{~m}$ (rmse $=$ root-mean-square error). However, relative low altitude has a greater amplitude of variation and gives rmse $92.7 \mathrm{~m}$ (Fig. 4b). The range of predictions is $53 \mathrm{~m}$ and $156 \mathrm{~m}$ respectively, and the lowest glaciers are predicted at aspects of $042^{\circ} \pm 41^{\circ}$ and $026^{\circ} \pm 15^{\circ}$. Variation in ELA with aspect is expected to be no more than half the predicted variation in lowest altitude, i.e. $78 \mathrm{~m}$ : the $53 \mathrm{~m}$ for mid-altitude is in line with expectations for ELA variation with aspect at this high latitude from the Evans and Cox (2005) model. (Aspect is rounded to a limited number of values (16), so overprinting of symbols could give a misleading visual impression. This has been avoided by using bars proportional in length to the number of glaciers with a given aspect, per $10 \mathrm{~m}$ class of altitude.)

These results for aspects giving lower glaciers are a little eastward from the $011^{\circ} \pm 8^{\circ}$ for vector mean aspect, but the latter confidence interval overlaps considerably with that for low altitude (which is defined more precisely than that for mid-altitude). The predicted 'lowest aspects' vary between

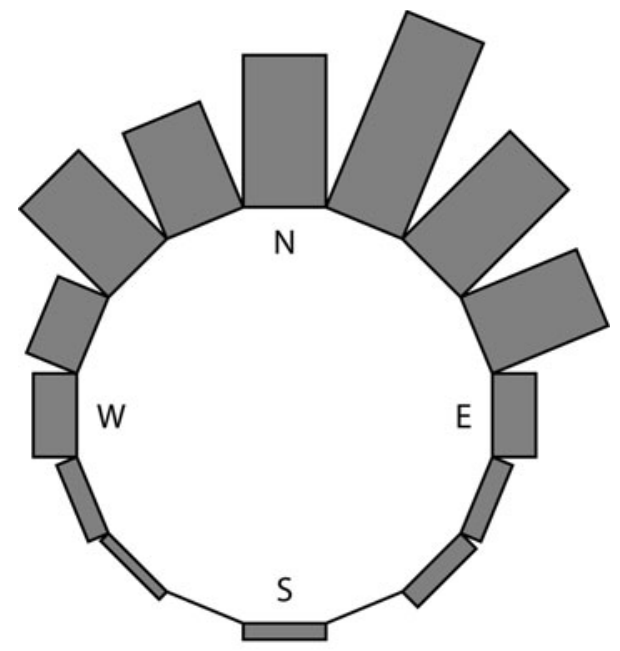

$011^{\circ} 61 \% n=205$

Fig. 2. Circular histogram of the aspects of glacier sources in northern and central Nordenskiöld Land, central Spitsbergen. Bar height is proportional to frequency of each aspect. Vector mean $\left({ }^{\circ}\right)$, vector strength (\%) and sample size $(n)$ are indicated. the four mountain blocks from $009^{\circ}$ to $030^{\circ}$ for low altitude, compared with $042^{\circ}$ overall for mid-altitude (Table 1 ).

The 205 glaciers have overall gradients of $6-36^{\circ}$, with a mean of $16^{\circ}$ compared with $6^{\circ}$ for local glaciers in the WGI. Their lengths vary from 0.3 to $6 \mathrm{~km}$, with a mean of $1.72 \mathrm{~km}$ compared with $8.86 \mathrm{~km}$ in the WGI. Height ranges per glacier vary between 70 and $750 \mathrm{~m}$, with a mean of $406 \mathrm{~m}$. Thus the glaciers of central Spitsbergen are not exceptionally long or low-gradient. A full inventory of all Svalbard glaciers, large and small, would probably produce average dimensions and gradients closer to those in other regions as tabulated in Evans (2006).

\section{OTHER ARCTIC RESULTS}

To provide context, Figure 5 compares mean aspects and lowest mid-altitude for the new Nordenskiöld Land data and for the eight other regions with WGI data that give significant results for both analyses. The WGI data were detrended by regressing on latitude and longitude as well as the sine and cosine of aspect (Evans and Cox, 2005). Seven regions show consistent results in that the 95\% confidence intervals on the two favoured aspects overlap, but two are
Longyear

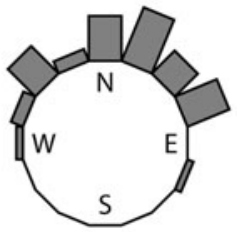

$013^{\circ} 72 \% n=40$

Berzelius

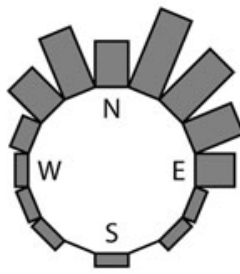

$018^{\circ} 53 \% n=77$
DeGeer

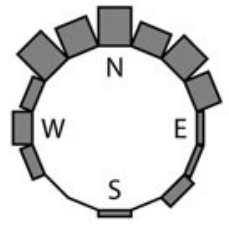

$358^{\circ} 50 \% n=42$

ColesGrøn

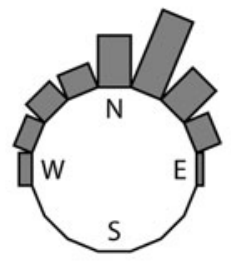

$009^{\circ} 75 \% n=46$
Fig. 3. Glacier source aspects for the four mountain blocks in northern and central Nordenskiöld Land, plotted as in Figure 2. 

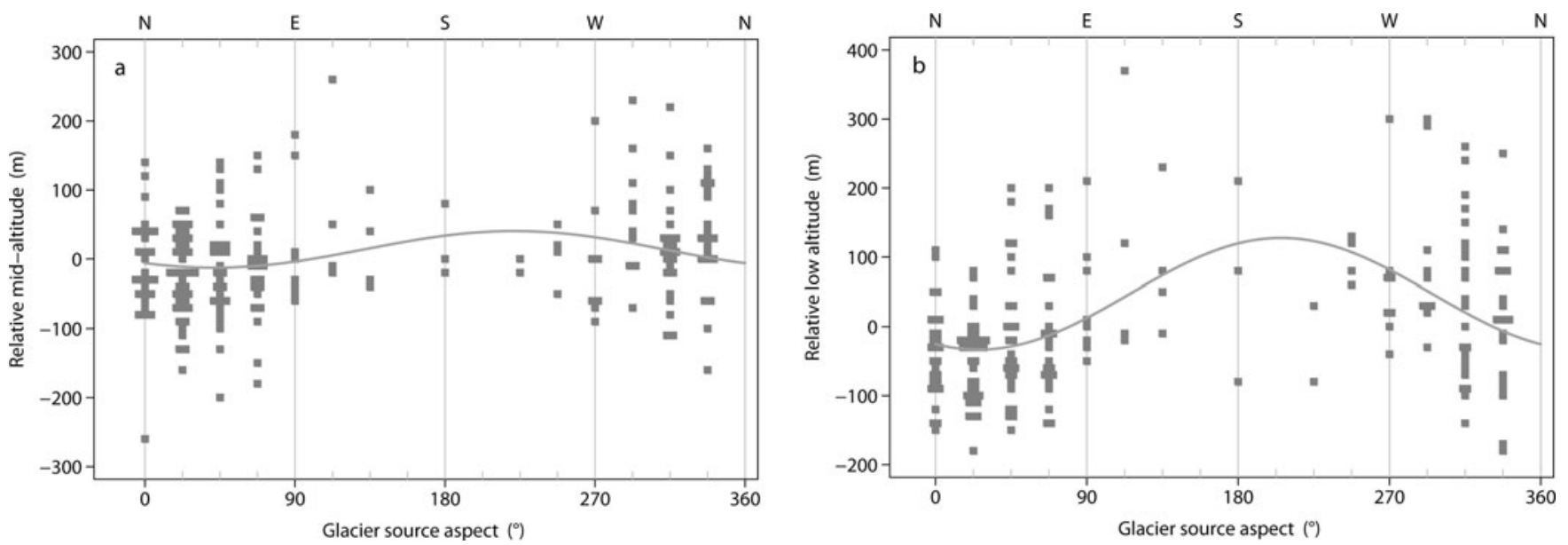

Fig. 4. Variation with aspect of (a) relative mid-altitude and (b) relative low altitude for glaciers in northern and central Nordenskiöld Land. Each square represents one glacier; altitude bins are $10 \mathrm{~m}$. The curves are fitted Fourier regressions (single sine and cosine terms). The regression lines are: (a) Relative mid-altitude $(\mathrm{m})=13.8-19.9 \cos$ (aspect) $-17.6 \sin$ (aspect), $R^{2}=0.03, p=0.027$. (b) Relative low altitude $(\mathrm{m})=47.2-72.6 \cos$ (aspect) $-34.7 \sin$ (aspect) $, R^{2}=0.15, p<0.0001$.

clearly inconsistent: Wrangel Island and northern Novaya Zemlya.

In Novaya Zemlya, as also in much of Svalbard, there is a mixture of local glaciers, outlet glaciers and ice caps. The northern part is dominated by a large, linear ice cap: a division at $74.65^{\circ} \mathrm{N}$ was used so that the whole of that ice cap falls on the northern side. Glacier numbers are clearly northward in the northern division, and near-eastward in the southern, where the exposure to strong westerly winds is greater. The southern result is consistent with the aspect of lowest glaciers, but for northern Novaya Zemlya the favoured aspects are almost opposed. Like the results in Figure 5 for all glaciers, results for the 93 local glaciers are inconsistent: $018^{\circ} \pm 26^{\circ}$ for vector mean, $133^{\circ} \pm 50^{\circ}$ for lowest, but the latter being insignificant. It is likely that these problematic results arise because the ice cap has local glaciers unevenly distributed around parts of its periphery.

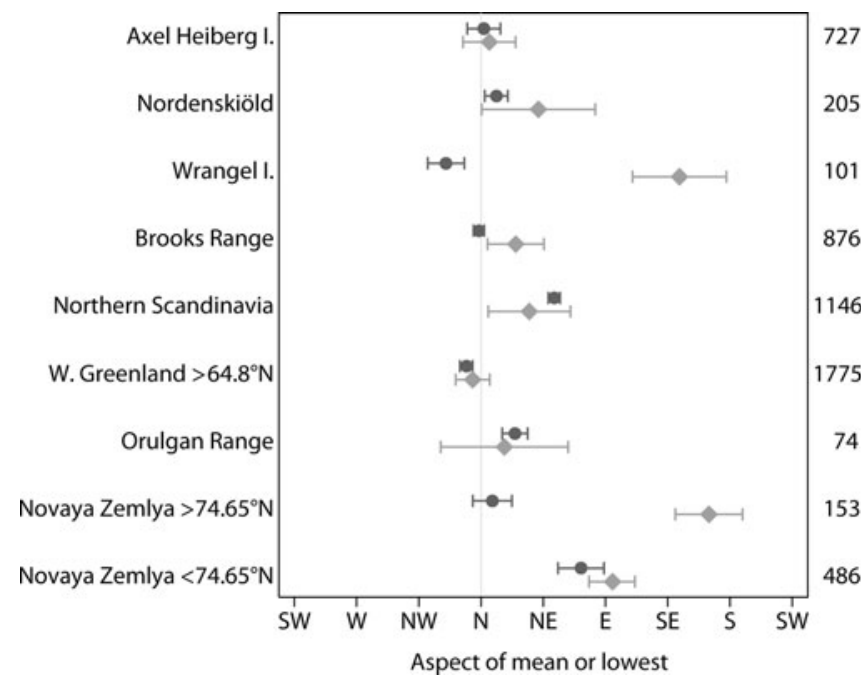

Fig. 5. Consistency of favoured aspects for glacier numbers (vector mean; dark circle) and glacier altitudes (lowest, from regression of mid-altitude on sine and cosine of aspect; light diamond). The bars show $95 \%$ confidence intervals on each. Numbers of glaciers (with the relevant data) in each region are shown on the right.
Dividing Novaya Zemlya further, the mean aspect of local glaciers is $013^{\circ} \pm 24^{\circ}$ north of $75^{\circ} \mathrm{N}, 063^{\circ} \pm 20^{\circ}$ south to $73.6^{\circ} \mathrm{N}$, and $087^{\circ} \pm 26^{\circ}$ further south. Results for all glaciers are similar, and for glaciers smaller than $10 \mathrm{~km}^{2}$ the means are respectively $003^{\circ} \pm 16^{\circ}, 052^{\circ} \pm 19^{\circ}$ and $079^{\circ} \pm 27^{\circ}$.

For Wrangel Island in the eastern Arctic $\left(71^{\circ} \mathrm{N}\right), 101$ local glaciers have a mean aspect of $335^{\circ} \pm 13^{\circ}$ and lowest altitudes at $144^{\circ} \pm 34^{\circ}$. All are small (0.1-1.2 km long and $1-20$ ha in area), and with vertical ranges of only $10-320 \mathrm{~m}$ they occupy hollows in an area of moderate relief. Few further data are available. (Nearby, the De Long Islands have only 15 glaciers, of which only 5 are local, so no significant results were found.)

All the other regions collated here show consistency between glacier numbers and glacier altitudes. For Axel Heiberg (around $80^{\circ} \mathrm{N}$ ), the Brooks Range (northern Alaska, $67-69^{\circ} \mathrm{N}$ ) and the Orulgan (northern Verkhoyansk) mountains in eastern Siberia $\left(67-69^{\circ} \mathrm{N}\right)$, favoured aspects are close to northward or north-northeast, as in Nordenskiöld Land $\left(78^{\circ} \mathrm{N}\right)$. For West Greenland between 64.8 and $71^{\circ} \mathrm{N}$, they are slightly west of north. Northern Scandinavian glaciers $\left(65-71^{\circ} \mathrm{N}\right)$ have a northeastward tendency.

WGI data for Axel Heiberg Island $\left(78-82^{\circ} \mathrm{N}\right)$ were originally provided by Ommanney (1969). Initial analysis of the WGI data was based on 241 local glaciers with data for altitude and accumulation-area aspect (Evans and Cox, 2005). Revisiting the data for this paper, we consider it reasonable to use ablation-area aspect wherever accumulation-area aspect was missing, thereby considerably increasing the size of the usable dataset. This gives vector means of $357^{\circ} \pm 10^{\circ}$ for all 1041 glaciers and $002^{\circ} \pm 12^{\circ}$ for the 728 local glaciers, with strengths of $23 \%$ and $24 \%$ respectively. Fourier regression analysis with various types of trend removal gives lowest glaciers on aspects between $338^{\circ}$ and $008^{\circ}$ (e.g. Fig. 6, for 727 local glaciers), confirming a consistent northward asymmetry on Axel Heiberg Island.

For additional context, the remainder of this section provides a brief discussion of additional Arctic regions with limited yet potentially useful glacier aspect data.

For two Russian areas, the Polar and sub-Polar Urals $\left(65-68^{\circ} \mathrm{N}\right.$ ) and the Putorana massif (in Siberia around $69^{\circ} \mathrm{N}$ ), 
with small numbers of glaciers (84 and 22 respectively, in the WGI) and high vector strengths (78\% and $85 \%)$, regressions for altitude are insignificant because of the lack of south- or west-facing glaciers. Vector means are $095^{\circ} \pm 9^{\circ}$ for the Urals and $025^{\circ} \pm 14^{\circ}$ for Putorana. Data for the Byrranga mountains (Taimyr peninsula, $76^{\circ} \mathrm{N}$ ) are not available.

Data for Jan Mayen Island $\left(71^{\circ} \mathrm{N}\right.$, south of Svalbard) are not available on the WGI (US National Snow and Ice Data Center (NSIDC)) website and were thus excluded from Evans and Cox (2005). They are, however, available on paper in Hagen and others (1993), from which a small dataset was produced for this study. As the 20 glaciers are on all slopes of the volcano Beerenberg, they are uniformly distributed with aspect. Despite their small number, they show a clear pattern of north-facing glaciers having an ELA $288 \mathrm{~m}$ lower (and mid-altitude $134 \mathrm{~m}$ lower) than south-facing: ELA $(\mathrm{m})=$ $753-144 \cos$ (aspect) $-6 \sin$ (aspect), $R^{2}=0.87, \quad p<0.0001$. Given the simple radial topography, the contrast is attributed to mesoclimatic differences.

A new inventory for Disko Island (at $70^{\circ} \mathrm{N}$ in West Greenland, a region within the WGI dataset above) has been produced by J. Yde (personal communication, 2006). Nonsurging glaciers show a moderately strong, significant northward tendency (mean $356^{\circ} \pm 18^{\circ}$ ), whereas surging glaciers tend closer to northeast (mean $036^{\circ} \pm 34^{\circ}$ ). The overall vector mean is $006^{\circ} \pm 16^{\circ}$ and strength $32 \%$, and altitudes are not significantly related to aspect.

The remaining areas of the Arctic with WGI data are Ellesmere Island, Canada, where the data cover only the southeast coast and are thus azimuthally biased; and the Russian western Arctic archipelagos, discussed in section 10 of Evans (2006). There, both Franz Josef Land and Severnaya Zemlya are dominated by ice caps, with local glaciers only in limited areas. Glacier numbers show northward tendencies but altitude data are far too incomplete to test their consistency. Even bigger data gaps occur in the remainder of the Canadian Arctic and North Greenland.

\section{DISCUSSION}

The consistent results from Nordenskiöld Land, where the topography gives equal possibilities of glacier development on slopes of any aspect, clearly imply that glacier mass balance is more positive on slopes facing between north and northeast. Winds are dominantly from easterly quarters in winter, but precipitation at Longyearbyen comes mainly with southwest winds (Bakkehøi, 2003). Snowdrifts mapped by Humlum (2002) from 1990 air photos imply dominant winds from the south-southeast, but his study area extended to the east coast of Spitsbergen. The general eastward rise of ELA and glacier mid-altitude in the present study area suggests that snow comes dominantly from west and southwest winds. This displaces favoured aspects a little east from north, but not enough to override north-south contrasts in solar radiation receipts.

The above reflects the general situation across the High Arctic, where seasonally variable winds have a limited net effect on glacier balance and thus on glacier aspect. Although polar easterlies are common north of $70^{\circ} \mathrm{N}$, most of the Arctic is affected by depressions driven by westerly circulation (Vowinckel and Orvig, 1970; Serreze and Barry, 2005). Thus the incidence of solar radiation becomes the dominant influence on the aspect of local glaciers, even though contrasts are weaker than in mid-latitudes. For

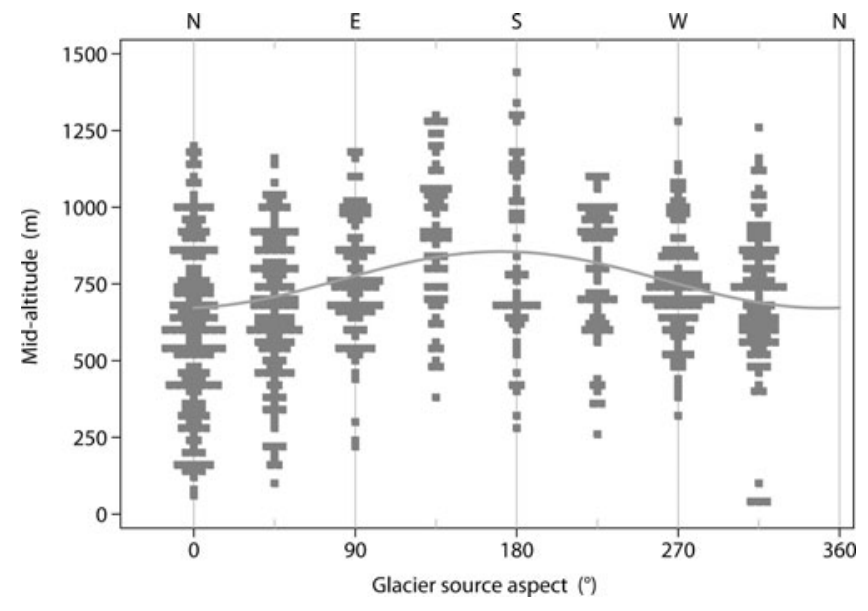

Fig. 6. Variation of mid-altitude with aspect for 727 local glaciers on Axel Heiberg Island, Canada; altitude bins are $20 \mathrm{~m}$. The regression line is: Mid-altitude $(\mathrm{m})=750-115 \cos ($ aspect $)+8$ $\sin ($ aspect).

northwest Spitsbergen $\left(79^{\circ} \mathrm{N}\right)$, distributed modelling by Arnold and others (2006) confirms the importance of slope gradient and aspect in controlling variation in summer solar radiation receipt and thus melt rates. The longer duration of sunlight evens out radiation receipt, but this is more than compensated by greater shading effects and contrasts in incidence, as the sun is lower in the sky at high latitudes. Thus, in Svalbard, as across most of the High Arctic, northward tendencies are general among local glaciers (Fig. 5). The main exception appears to be in southern Novaya Zemlya, where more easterly aspects are suggestive of the effects of west winds increasing southward, culminating in the eastward mean glacier aspect in the Polar and sub-Polar Urals where the existence of most glaciers is due to wind drifting snow to lee slopes.

\section{CONCLUSIONS}

The incompleteness of first-generation WGI data for small glaciers produces inconsistencies in the analysis of local asymmetry, in that the aspect of lowest glaciers differs significantly from mean glacier aspect in some WGI Arctic datasets. New inventory data for central Spitsbergen, covering smaller glaciers as do WGI data for most other regions, show a glacier tendency to north-northeast aspects, consistent for both numbers and altitudes, for four mountain blocks. This becomes apparent only when small glaciers, which are more sensitive to aspect, are inventoried. The answer to question 3 of the introduction is thus positive, and to questions 1,2 and 4, negative: the previous inconsistency is essentially related to incompleteness in WGI coverage of small glaciers. The 241 local glaciers with altitude and aspect information tabulated in Hagen and others (1993) and in the WGI grossly underestimate the number of local glaciers in Svalbard, and under-represent in particular the smaller, less geometrically complex glaciers that are more likely to yield aspect-climate relationships.

Re-analysing WGI data from Axel Heiberg Island also shows consistency between glacier numbers and altitudes, and reflects the general pattern across the Arctic, with only two remaining anomalies: Wrangel Island and northern Novaya Zemlya. Such consistency supports the interpretation 
that glacier aspect tendencies reflect azimuthal variations in glacier mass balance. The northward tendency of most Arctic glaciers is strong evidence for the dominating influence of solar radiation incidence. Solar radiation effects give more glaciers, and lower glaciers, with northward and northeastward aspects, but wind effects are less clear.

This study demonstrates the value of interrogating glacier inventory data as an economical method for retrieving regional climate information even without recourse to more intensive field measurements, which it complements. However, it also demonstrates that inconsistencies in the coverage of current inventory data must be taken into account when comparing such information across different regions. Like parts of the WGI, modern satellite-based inventories tend to exclude the smallest glaciers. The next generation of inventories needs to provide more complete coverage of these climatically important glaciers, and to avoid missing data for important attributes (e.g. size, altitude, aspect and classification).

\section{ACKNOWLEDGEMENTS}

We are grateful to J. Yde and $\mathrm{H}$. Jiskoot for supplying inventory data, to the Durham University Design and Imaging Unit for Figure 1, and to two referees for very useful suggestions. The WGI data was downloaded from NSIDC at Boulder, CO (NSIDC, 1999, updated 2005).

\section{REFERENCES}

Arnold, N.S., W.G. Rees, A.J. Hodson and J. Kohler. 2006. Topographic controls on the surface energy balance of a high Arctic valley glacier. J. Geophys. Res., 111(F2), F02011. (10.1029/2005JF000426.)

Bakkehøi, S. 2003. Landscape, climate and environment at Spitsbergen. In Rike, A.G., ed. Permafrost response to environmental and industrial loads. Final Report Strategic Institute Programme 1999-2003. Oslo, Norwegian Geotechnical Institute, $17-30$

Cox, N.J. 2006. In praise of trigonometric predictors. Stata J., 6(4), 561-579.

Dowdeswell, J.A. and J.O. Hagen. 2004. Arctic glaciers and ice caps. In Bamber, J.L. and A.J. Payne, eds. Mass balance of the cryosphere. Cambridge, Cambridge University Press, 527-557.

Evans, I.S. 1977. World-wide variations in the direction and concentration of cirque and glacier aspects. Geogr. Ann., 59A(3-4), 151-175.

Evans, I.S. 2006. Local aspect asymmetry of mountain glaciation: a global survey of consistency of favoured directions for glacier numbers and altitudes. Geomorphology, 73(1-2), 166-184.

Evans, I.S. and N.J. Cox. 2005. Global variations of local asymmetry in glacier altitude: separation of north-south and east-west components. J. Glaciol., 51(174), 469-482.
Fisher, N.I. 1993. Statistical analysis of circular data. Cambridge, Cambridge University Press.

Hagen, J.O., O. Liestøl, E. Roland and T. Jørgensen. 1993. Glacier atlas of Svalbard and Jan Mayen. Nor. Polarinst. Medd. 129.

Hagen, J.O., K. Melvold, F. Pinglot and J.A. Dowdeswell. 2003. On the net mass balance of the glaciers and ice caps in Svalbard, Norwegian Arctic. Arct. Antarct. Alp. Res., 35(2), 264-270.

Humlum, O. 2002. Modelling late 20th-century precipitation in Nordenskiöld Land, Svalbard, by geomorphic means. Nor. Geogr. Tidsskr., 56(2), 96-103.

Humlum, O. and W. Ziaja. 2002. Correspondence. Discussion of 'Glacial recession in Sarkappland and central Nordenskiöldland Spitsbergen, Svalbard during the 20th century' by Wieslaw Ziaja. Arct. Antarct. Alp. Res., 34(2), 226-229.

Jiskoot, H., T. Murray and P. Boyle. 2000. Controls on the distribution of surge-type glaciers in Svalbard. J. Glaciol., 46(154), 412-422.

Liestøl, O. 1993. Glaciers of Europe - glaciers of Svalbard, Norway. In Williams, R.S., Jr and J.G. Ferrigno, eds. Satellite image atlas of glaciers of the world. Denver, CO, United States Geological Survey, E127-E151. (USGS Professional Paper 1386-E.)

National Snow and Ice Data Center (NSIDC). 1999, updated 2005. World Glacier Inventory. Boulder, CO, World Glacier Monitoring Service. National Snow and Ice Data Center/World Data Center for Glaciology. CD-ROM

Norsk Polarinstitutt. 2005. Svalbard: 1:100,000. Tromsø, Norsk Polarinstitutt. (Topographic Map Series. Sheets C9 Adventdalen, B10 Van Mijenfjorden and B9 Isfjorden.)

Nuth, C., J. Kohler, H.F. Aas, O. Brandt and J.O. Hagen. 2007. Glacier geometry and elevation changes on Svalbard (1936-90): a baseline dataset. Ann. Glaciol., 46, 106-116.

Ommanney, C.S.L. 1969. A study in glacier inventory: the ice masses of Axel Heiberg Island, Canadian Arctic Archipelago. Montréal, Que., McGill University. (Axel Heiberg Island Research Reports Glaciology 3.)

Raper, S.C.B. and R.J. Braithwaite. 2009. Glacier volume response time and its links to climate and topography based on a conceptual model of glacier hypsometry. Cryosphere, 3(2), 183-194.

Schiefer, E., B. Menounos and R. Wheate. 2008. An inventory and morphometric analysis of British Columbia glaciers, Canada. J. Glaciol., 54(186), 551-560.

Serreze, M. and R.G. Barry. 2005. The Arctic climate system. Cambridge, etc., Cambridge University Press.

Vowinckel, E. and S. Orvig. 1970. The climate of the north polar basin. In Orvig, S., ed. Climates of the polar regions. New York, Elsevier, 129-252. (World Survey of Climatology 14.)

Ziaja, W. 2005. Response of the Nordenskiöld Land (Spitsbergen) glaciers Grumantbreen, Håbergbreen and Dryadbreen to the climate warming after the Little Ice Age. Ann. Glaciol., 42, 189-194.

Ziaja, W. and R. Pipała. 2007. Glacial recession 2001-2006 and its landscape effects in the Lindströmfjellet-Håbergnuten mountain ridge, Nordenskiöld Land, Spitsbergen. Pol. Polar Res., 28(4), 237-247. 